\title{
文化遺産「熊野参詣道伊勢路」の管理運営計画策定における地域住民の関わり方
}

\section{The Way of Participation of Local people on the Developing Heritage Management Plan in Kumano Pilgrimage Route Iseji}

\author{
伊藤 文彦* 伊藤 弘** 武 正憲** \\ Fumihiko ITO Hiromu ITO Masanori TAKE
}

\begin{abstract}
This study aims to clarify the way of participation of the local people on the developing heritage management plan through the case study on the Kumano pilgrimage route Iseji. It became more important to emphasise the role of community in the heritage conservation context, but it needs further analysis of the change of the contents written on the management plan through the years. The "Kumano-Kodo Action Program" is a good example because it has four editions in 10 years. As a result of this study, local people was the main organiser at the first edition, but regional government gradually became the main organiser at the later versions. The first version required local people and visitors the responsibility for the conservation of heritage and natural environment, but the later editions prize the residents for their voluntary activities and promote the hospitality for the visitors. It can be said that management plan needs the way of checking the situation of implementation and that continued participation of the local people for the developing the management plan is essential for the continued participation of the local people in the management activities.
\end{abstract}

Keywords: Heritage Conservation, Management Plan, Local People キーワード：遺産保護,管理計画, 地域住民

\section{1. 背景と目的}

近年,行政の政策課題として,行政と地域住民の協働が推奨され ている 1)。文化遺産や自然遺産の管理運営においても,地域住民が 参加することが推奨されている。例えば,遺産保護の世界的枠組み である世界遺産条約においては,2007年の第 31 回世界遺産委員会 において「先住的,伝統的,地域的コミュニティの参画が条約の履行 には極めて重要である」との認識に基づき,世界遺産委員会の戦略 的目標の 1 つにコミュニティ」が追加されている2)。また,世界 遺産条約の事務局であるユネスコとその諮問機関である ICCROM,ICOMOS,IUCN は「遺産が複雑化するにつれて管理の 実践の進化が求められており，(中略）管理運営のアプローチは遺 産の管理運営のより広範でより包括的なアプローチへ,そしてコミ ユニティの参画がより強調されるものへという変化に対応しなけ ればならない(これらはごく最近になって世界の各地で見られる ようになったものである)。」と指摘する3)。日本国内では稲葉信子 が世界遺産委員会の求める遺産のマネジメントシステムの議論の 中で遺産マネジメントを「遺産の価值に変化を与える要素の管理 にかかわる利害関係者の合意形成のプロセス」と定義している4)。 こうした考え方に基づき,日本国内でも「地域住民」が策定に参加 した文化遺産の管理運営計画として「石見銀山行動計画」5)や「富 士山世界文化遺産富士宮市行動計画」6)等が登場している。

2004 年に『紀伊山地の霊場と参詣道』の構成資産の一つとして, 一部が世界遺産に登録された熊野参詣道伊勢路（以下,伊勢路）は, 伊勢から熊野までの巡礼路としての価值が見出され、継続して管 理が必要な遺産である7)。ここでは、世界遺産登録を控えた 2003 年に,その管理運営計画を示寸『「熊野古道」アクションプログラム (以下, 熊野古道 AP)』が策定された。策定の事務局を務めた平野 昌は,熊野古道 AP の策定経過を地域住民主体の策定であるとし 8), 西川亮は,策定参加者や内容加官民協働による世界遺産の保全・ 活用の証拠として評価する 9)など,地域住民と行政の協働による遺 産保護の好例として評価されている ${ }^{10)}$ 。しかし, 熊野古道 AP は当
初の計画策定後 10 年以上が経過しておりここの間 8 編の関連文書 が発行されている。その内容は,管理運営の対象である伊勢路を取 り巻く状況（利用および保護の仕方）が管理運営の結果変化し,そ れとともに地域住民の関わり方も変化していることが考えられ,こ れらも合わせて評価する必要がある。また,このような長期間にわ たって修正された遺産の管理運営計画について,特に対象となる遺 産を取り巻く状況の変化と,策定における地域住民の関わり方との 関係からその変化をみたものはなく,改めてその関係をみることは, 今後の管理運営計画策定に当たって意義あることと言える。

本研究は, 『熊野古道 $\mathrm{AP}$ を対象に,管理運営計画の変化を明ら かにし,管理運営の対象となる遺産を取り巻く状況の変化と計画策 定における地域住民の関わり方の関係から考察し,管理運営計画策 定のあり方について検討することを目的とする。

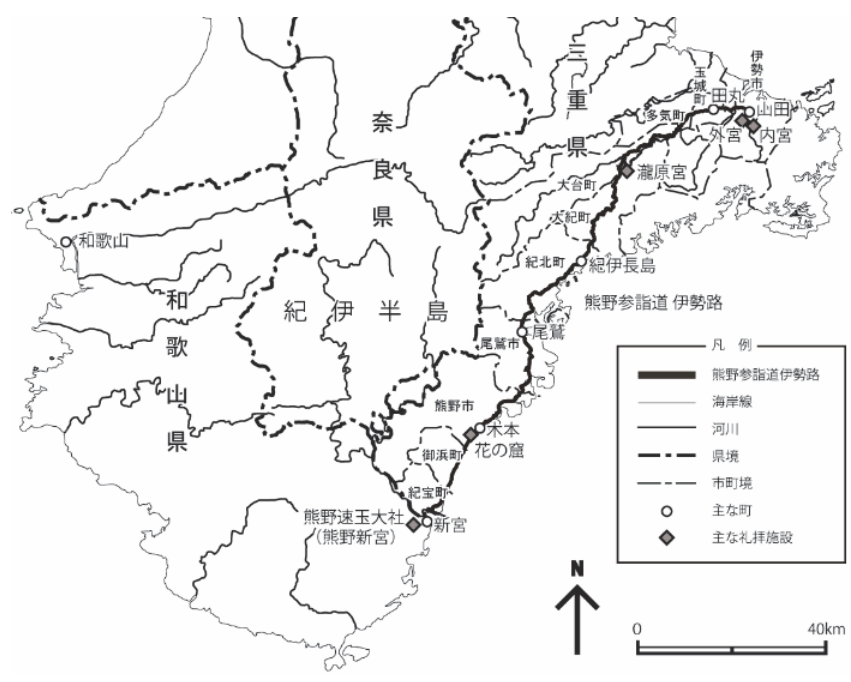

図-1 熊野参詣道伊勢路位置図 


\section{2. 研究方法}

\section{（1）『熊野古道 AP』の概要}

熊野古道 AP とそれに関連する計画書は全部で 8 種類ある（表 -1)。世界遺産登録前の 2003 年 (平成 15) 3 月に最初の熊野古 道 $\mathrm{AP}$ が策定された。この計画には,行動計画のみを記述した『平 成 15 年度編』, 『16 年度編』が別冊として附属する。その後, 熊 野古道 AP の各編が示寸計画対象期間の未年に,本編の改定・追記 が行われている。改定・追記は世界遺産登録後の 2005 年 (平成 17）,世界遺産に登録されて 5 年後の 2008 年 (平成 20)，世界遺産 に登録後 10 年以上経過した 2015 年 (平成 27) にそれぞれ行われ た。このほか,時点修正や編集上の錯誤の修正などの極めて軽微な 改定が 2004 年 (平成 16) と 2006 年（平成 18）に 2 度行われて いる。以上より本稿においては,2003 年,2005 年,2008 年,2015 年 に策定・改定・追記された熊野古道 AP (以下,年代順に熊野古道 $\mathrm{AP} 1$, 熊野古道 $\mathrm{AP} 2$, 熊野古道 $\mathrm{AP} 3$, 熊野古道 $\mathrm{AP} 4$ ）を対象とする。

\section{（2）方法}

熊野古道 AP の内容は,2017 年現在策定済みである 8 種類の計 画書から把握した。まず,熊野古道 AP1について, 地域住民が関係 する,a）策定経過（策定参加者と策定方法）,b）遺産の保護,c）利 用 (ツーリズム) ,d) 計画の実施方法の 4 項目について確認した。

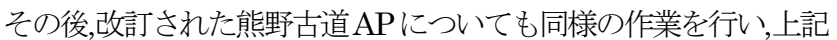
4 項目について,内容の変化を把握した。遺産を取り巻く状況は,熊 野古道 $\mathrm{AP} 1$ 策定の前年度である平成 13 年度から熊野古道 $\mathrm{AP} 4$ 策 定の次年度である平成 28 年度までの, 熊野古道 $\mathrm{AP}$ および地域住 民に関係すると思われる,女）世界遺産登録（い）人口および入込客 数,う）住民組織,え）県の施策の 4 項目について把握した。あ）は 世界遺産登録記念誌 11)力ら，い） は三重県等の公表資料 12)13)力ら， う）は新聞記事 14)から,え）は行政文書（予算一覧表）15)加把握 した。

\section{3. 結果}

\section{（1）熊野古道 AP1 の内容}

1）策定経過（策定参加者と策定方法）

策定には,市民プランナー (一般公募で集まった地域住民), サポ 一ター (県内で活躍する市民活動・出版・観光などの専門家) ・ 行 政職員（国・県・市町村）が参加し,ワークショップにより内容を 検討している。これに危機管理・歴史・建築・ユニバーサルデザイ ン・防災・林業といった各分野の専門家がアドバイザーとして参 画していた。事務局は三重県が担うが,行政職員だけでなくライタ 一やボランティア団体の代表が参加している。地域住民と行政だ
けでなく,多様な主体が,策定者,助言者,事務局員として参加し,それ らの意見がワークショップにより計画に反映され,文書にまとめら れた。また,ワークショップを補完する目的で関係者へのヒアリン グも行われた。

2) 遺産の保護

世界遺産登録されることを見越して,登録後の「保全と活用の前 提となること」として,世界遺産条約や文化財保護法,保存管理計画, 整備活用計画を考え,具体的に行動していく必要があると述べてい る。また,文化的景観の説明と,その保全および活用の必要性を示し たうえで,保全する責任と次世代への継承を目的に,保全に関する 責任を果たすことを提案している。このように,遺産に関係するす べての人々に遺産保護の責任を果たすことを求めていると言える。 3) ツーリズム

伊勢路の特徵は「聖地を目指寸巡礼路であったということ」,「「伊 勢からの道」であるということ」にあり,「歩く」ということと「道」 ということ」を基本において実施していくことを明示している。 具体的には,平成の熊野参詣道として実際に伊勢から熊野三山まで 歩くことができるようにする企画の実施や受入態勢の整備のほか, 宿泊施設も近世において巡礼者に提供された善根宿や宿坊を意識 して設置していくことを検討するとしている。このように,本来の 巡礼路としての性格を基盤として展開しようとしていることが確 認できた。また，「環境を損なわず,地域のありのままを一緒に楽し もうというのがエコツーリズム」として,環境を守り伝え,その姿か ら来訪者に感じ学んでもらうエコツーリズムを実践するとしてい る。具体的には，「熊野古道ルール」の普及やゴミの持ち帰りなど， 来訪者に社会的責任を求める内容を示している。さらに,トイレな どの施設整備は必要最小限におさえ, 公共交通機関の利用促進とパ 一ク\&ライドによる交通拠点周辺での駐車場整備による環境負荷 低減を図るなど,保護を優先させた内容となっている。

4）計画の実施方法

個々のアクションは住民や民間事業者等実施主体が自主的に行 い,地域住民,市民団体,事業者,行政機関等を含む「熊野古道にかか わる全ての人」を構成員とする会議体「熊野古道協働会議」におい て全体の進行管理を行うとしている。実行状況は, 1 年ごとに上記 熊野古道協働会議による「計画」「実行」「チェック」「見直し」と いう P D C Aサイクルを回すマネジメントシステムの実施によっ て管理するとしている。さらに管理運営計画の対象期間は 3 年で あり，「原則として 3 年ごとに大きな見直しを行うことで新しい環 境の変化に対応」するとしている。本計画は,前述の遺産の保護お よびツーリズムの方針に従って,熊野古道協議会議の管理のもとで

\begin{tabular}{|c|c|c|c|c|c|c|c|c|}
\hline 表題 & $\begin{array}{l}\text { 「熊野古道」アクシ } \\
\text { ヨンプログラム }\end{array}$ & $\begin{array}{l}\text { 「熊野古道」アクシ } \\
\text { ヨンプログラム }\end{array}$ & $\mid \begin{array}{l}\text { 「熊野古道」アクシ } \\
\text { ヨンプログラム }\end{array}$ & $\mid \begin{array}{l}\text { 「熊野古道」アクシ } \\
\text { ヨンプログラム }\end{array}$ & $\begin{array}{l}\text { 熊野古道アクション } \\
\text { プログラム } 2\end{array}$ & \begin{tabular}{|l|} 
\\
熊野古道アクション \\
プログラム 2
\end{tabular} & $\begin{array}{l}\text { 熊野古道アクション } \\
\text { プログラム } 2 \text { 追記 } \\
\text { 編 }\end{array}$ & $\begin{array}{l}\text { 熊野古道アクション } \\
\text { プログラム } 3\end{array}$ \\
\hline 副題 & $\begin{array}{l}\text { 〜世界遺産登録をめ } \\
\text { ざす熊野古道の保全 } \\
\text { と活用のために〜 }\end{array}$ & $\begin{array}{l}\text { 世界遺産登録をめ } \\
\text { ざす熊野古道の保全 } \\
\text { と活用のために〜 }\end{array}$ & $\begin{array}{l}\text { 世界遺産登録をめ } \\
\text { ざす熊野古道の保全 } \\
\text { と活用のために〜 }\end{array}$ & $\begin{array}{l}\text { 世界遺産登録をめ } \\
\text { ざす熊野古道の保全 } \\
\text { と活用のために〜 }\end{array}$ & $\begin{array}{l}\text { 世界遺産・熊野古道 } \\
の \text { 保全と活用のため } \\
\text { に }\end{array}$ & $\begin{array}{l}\text { 世界遺産・熊野古道 } \\
\text { の保全と活用のため } \\
\text { に }\end{array}$ & $\begin{array}{l}\text { ～世界遺産登録 } 5 \\
\text { 周年を迎えるにあた } \\
\text { って〜 }\end{array}$ & $\mid \begin{array}{l}\text { 保全と活用のための } \\
\text { 活動指針 }\end{array}$ \\
\hline $\begin{array}{l}\text { 発行者 } \\
\text { (表紙) }\end{array}$ & 三重 県 & 三重 県 & 三重 県 & 三重 県 & $\begin{array}{c}\text { 熊野古道協動会議 } \\
\text { 三重県 }\end{array}$ & $\begin{array}{c}\text { 熊野古道協働会議 } \\
\text { 三重県 } \\
\end{array}$ & 熊野古道協働会議 & 熊野古道協㗢会議 \\
\hline $\begin{array}{l}\text { 発行者 } \\
\text { (奥付) }\end{array}$ & $\begin{array}{l}\text { 三重県（地域振興部 } \\
\text { 東紀州活性化プロジ } \\
\text { エクトグループ） }\end{array}$ & $\begin{array}{l}\text { 三重県（地域振興部 } \\
\text { 東紀州活性化プロジ } \\
\text { エクトグループ） }\end{array}$ & $\begin{array}{l}\text { 三重県（地域振興部 } \\
\text { 東紀州活性化・地域 } \\
\text { 特定プロジェクト) }\end{array}$ & $\begin{array}{l}\text { 三重県（地域振興部 } \\
\text { 東紀州活性化・地域 } \\
\text { 特定プロジェクト） }\end{array}$ & $\begin{array}{l}\text { 三重県（地域振興部 } \\
\text { 東紀州活性化・地域 } \\
\text { 特定プロジェクト） }\end{array}$ & $\begin{array}{l}\text { 三重県（地域振興部 } \\
\text { 成東紀州活性化・地域 } \\
\text { 特定プロジェクト) }\end{array}$ & 三重県 & $\begin{array}{l}\text { 熊野古道 } \\
\text { 協働会議 }\end{array}$ \\
\hline 発行年月日（表紙） & 平成 15 年 3 月 & 平成 15 年 3 月 & 平成 15 年 3 月 & 平成 16 年 6 月 & 平成 17 年 7 月 & 平成 17 年 7 月 & 平成 20 年 12 月 & 平成 27 年 3 月 \\
\hline 発行年月日 (奥付) & 平成 15 年 3 月 & 平成 15 年 3 月 & 平成 16 年 3 月改定 & 平成 16 年 6 月 & 平成 17 年 7 月 & 平成 18 年 3 月改定 & 平成 20 年 12 月 & 平成 27 年 3 月 \\
\hline 備考 & 熊野古道AP1 & $\begin{array}{l}\text { 年度編別冊 } \\
\text { アクションのみ記載 }\end{array}$ & \begin{tabular}{|l|} 
内容の一部（ロゴマ \\
一ク,関係団体リス \\
卜,熊野古道に係わ \\
る法律等について） \\
を修正
\end{tabular} & $\begin{array}{l}\text { 年度編別冊 } \\
\text { アクションのみ記載 }\end{array}$ & 熊野古道AP2 & \begin{tabular}{|l|} 
内容の一部（三重県 \\
立熊野古道センタ \\
の名称,関係団体名 \\
簿節番号のミス \\
を修正
\end{tabular} & 熊野古道AP3 & 熊野古道AP4 \\
\hline
\end{tabular}


多様な主体が自主的に事業に取り組み,状況に応じた展開を図ろう とするものであったといえる。

\section{（2）『「熊野古道 AP』の記載内容の変化}

1) 策定経過（表一2）

AP2 以降も事務局は三重県が担うが,ライターやボランティア 団体の代表は熊野古道 AP3 以降見られなくなる。また, 熊野古道 $\mathrm{AP} 2$ 以降ワークショップは行われなくなり, 熊野古道 $\mathrm{AP} 2$ では, 学 識経験者, N P O, 事業者,一般参加者 (地域住民), 行政 (国,県,市町) が参加するシンポジウム, 熊野古道伊勢路シンポジウム 〜これか らの世界遺産熊野古道を考える〜」が行われた。熊野古道 AP2 以 降,熊野古道関係者が事前申込により自由に参加できる熊野古道協 働会議が行われており,以降熊野古道 $\mathrm{AP} 4$ まで継続している。これ らのシンポジウム・会議では, 事務局が作成したアクションプログ ラム案を協議・承認している。また, 熊野古道 AP4 では事務局案を 作成するため, 熊野古道関係者,行政担当者等で構成する検討会議 を 3 回にわたり開催」している。このように,地域住民が意見を述 べる機会はありながらも,アクションプログラムの策定主体は一般 公募の地域住民から行政へと変化していることが確認できた。

ヒアリングは熊野古道 AP1 から熊野古道 AP4 まで行われてい るが,その対象者は変化する。熊野古道 AP1 では「関係者へのヒア リングも積極的に行い,検討成果に盛り込」んだとし,ワークショッ プの補完に利用していた。ワークショップが行われなくなった熊 野古道 AP2 では「学識経験者や地域の関係者,さらには行政の担当 者等から,意見や現状」を聞き取ったとし, 熊野古道 AP3 では, 「研 究者,メディア関係者,プロモーション専門家, 首都圈から何度もこ の地域を来訪されているファンの方, 世界遺産登録前後から深くか かわっておられる地元関係者」を対象に, 『熊野古道及び周辺の魅 力」「プロモーションのあり方,手法」』をヒアリングしたとしてお り,外部への情報発信を強く意識していることが理解できる。なお, 熊野古道 AP4では「これまでの熊野古道の保全と活用に係る取組 について,その成果と課題等を把握」するため, 保存会・語り部等の 市民活動団体,有識者を対象に行っており,意向を聞くというより も現状把握を目的としている。

熊野古道AP2 からはアンケート調査が採用されている。熊野古 道AP2 では熊野古道関係者を対象に現状評価を調査している。熊 野古道 AP3 では地域住民,行政職員に「これまでの活動をどう評価 するか。また,それらについて将来に向けてどう取り組むべきか」 および「世界遺産登録 5 周年を迎えるにあたって,どのようなこと に取り組めば地域がより良い方向にむかうか。また,県が想定して いる 5 周年記念事業についてどう考えるか」を問うている。熊野 古道 AP4では「熊野古道関係者」を対象に「取組を検証し,課題や 今後の取組の方向性を見出すことを目的」として実施している。 加えて,来訪者を対象に, 来訪者の属性や動機, 伊勢路の魅力之課題, 再来訪意向等の把握を実施しており, 来訪者の意向の把握を強く意 識していることが理解できる。

策定経過は, 管理運営計画がより広範な地域住民の意見を汲み 取ろうとする当初の在り方から, 熊野古道関係者と行政の限定的な 意見,来訪者の意向を汲み取るものへと変化していた。

2）遺産の保護（表一3）

遺産の保護については,取り扱いの優先順位を示寸章に大きな変 化がみられた（表一 3 )。熊野古道 $\mathrm{AP} 1$ においては第 2 章で取り扱 われていた「関連する法と条例」の解説は熊野古道 AP2 に第 3 章 第 5 節一と縮小し, 熊野古道 AP4 においては,本編ではなく, 資料 編第 5 節で記載される。文化財保護については,熊野古道 AP3 に おいては,「行政の役割」として「文化財保護の視点から,法や制度 を活用して,有形無形の熊野の価值を積極的に保全していく取組が 求められ」るとあり,特定の部署に限定されていなかった。熊野古 道AP4においては,文化財保護は,市町教育委員会, 県教育委員会が
中心的役割を,ボランティア団体である保存会と国が一部役割を担 うとされ,そのほかの関係者には全く役割が期待されていない。

一方,遺産の保全を実施する保存会に対しては,熊野古道 AP2 に おいて「語り部・保存会等の住民組織との連携による結合的な保 存体制の確立」「保存会活動に対する支援」が明記される。熊野古 道AP3 では「地域の活動を支援することが必要と考え」，「さまざ まな地域の活動に目を向け,顕彰することにより,その活動に対す る評価を高め,次世代への継承を考え」るとしている。熊野古道 AP4では「熊野古道を守り伝える活動をサポートする支援体制の 強化を図り」「保存会や語り部の会をはじめ（中略）それらの活動 に対する顕彰等を通じて,地域に周知を図るとともに次世代一の継 承の促進をめざ」すとしており,当初は官民連携による保存体制が 企図されていたのが,行政と保存会（住民団体）に分かれてしまっ ていることがうかがえる。

このように, 熊野古道 AP1 で遺産に関係するすべての人々に求 めていた遺産保護の責任は,行政の文化財保護担当部局が果たす心゙ き責任として限定されるように変化したといえる。

3） ツーリズム（表一 3 )

熊野古道 AP2 では, 熊野古道 AP1 のコンセプトに基づいてルー 卜の選定,整備,情報発信,踏破の催しなどが企画され,沿道集落の魅 力創生,環境整備などが計画されるなど,その具現化が図られてい る。宿泊施設も宿坊の整備を進めることを目指寸など,引き続き巡 礼路のコンセプトを継承していることが理解できる。熊野古道 AP3 では,引き続き「文化観光のさらなる推進」を図るとするに留 まっており,具体的な内容は示されていない。熊野古道 AP4 では, 通し歩きのイベントなどが計画されながらも,宿泊施設は,活動事 例として「空き家の活用等による交流促進 宿泊・休息施設,チャ レンジショップ等への活用」や「宿泊施設,休息施設の充実 民泊，

\section{表一2 策定経過の变遷}

\begin{tabular}{|l|c|c|c|c|}
\hline 策定方法 & $\begin{array}{c}\text { 文献 } \\
\text { AP1 }\end{array}$ & $\begin{array}{c}\text { 熊野古道 } \\
\text { AP2 }\end{array}$ & $\begin{array}{c}\text { 熊野古道 } \\
\text { AP3 }\end{array}$ & $\begin{array}{c}\text { 熊野古道 } \\
\text { AP4 }\end{array}$ \\
\hline 市民事務局員 & $\bigcirc$ & $\bigcirc$ & & \\
\hline 行政向け説明会 & $\bigcirc$ & & & \\
\hline ワークショップ & $\bigcirc$ & & & \\
\hline シンポジウム & & $\bigcirc$ & & $\bigcirc$ \\
\hline 熊野古道協働会議 & & $\bigcirc$ & $\bigcirc$ & $\bigcirc$ \\
\hline 関係者検討会議 & & & & $\bigcirc$ \\
\hline 関係者ヒアリリグ & $\bigcirc$ & $\bigcirc$ & $\bigcirc$ & $\bigcirc$ \\
\hline 関係者アンケート & & $\bigcirc$ & $\bigcirc$ & $\bigcirc$ \\
\hline 来訪者ヒアリング & & & & $\bigcirc$ \\
\hline 来訪者アンケート & & & & : 該当する項目 \\
\hline
\end{tabular}

表-3 策定内容の変遷

\begin{tabular}{|c|c|c|c|c|c|}
\hline \multicolumn{2}{|c|}{ 項目 文献 } & $\begin{array}{c}\text { 熊野古道 } \\
\text { AP1 }\end{array}$ & $\begin{array}{l}\text { 熊野古道 } \\
\text { AP2 }\end{array}$ & $\begin{array}{l}\text { 熊野古道 } \\
\text { AP3 }\end{array}$ & $\begin{array}{c}\text { 熊野古道 } \\
\text { AP4 }\end{array}$ \\
\hline \multirow{3}{*}{ 保 } & 「法と条例」 & 第2 章 & $\begin{array}{l}\text { 第3竡 } \\
\text { 第 } 5 \text { 節 }\end{array}$ & 行政の役割 & $\begin{array}{l}\text { 資料編 } \\
\text { 第5 } 5 \text { 䬶 }\end{array}$ \\
\hline & 住民組織 & 自主的な取組 & $\begin{array}{l}\text { 連携 } \\
\text { 支援 }\end{array}$ & $\begin{array}{l}\text { 支援 } \\
\text { 頻彰 }\end{array}$ & $\begin{array}{l}\text { 支援 } \\
\text { 彰 }\end{array}$ \\
\hline & 刘来訪者 & $\begin{array}{l}\text { 社会的責任 } \\
\text { 冰 }\end{array}$ & $\begin{array}{l}\text { 社会的責任 } \\
\text { 残少 }\end{array}$ & $\begin{array}{c}\text { 二ーズへの } \\
\text { 刘応 }\end{array}$ & おもてなし \\
\hline \multirow{4}{*}{\begin{tabular}{|l} 
y \\
$\vdots$ \\
J \\
ズ \\
厶
\end{tabular}} & ツーリズム & $\begin{array}{c}\text { エコ } \\
\text { ツーリズム }\end{array}$ & $\begin{array}{l}\text { カルチュラル } \\
\text { ツーリズム }\end{array}$ & 文化観光 & $\begin{array}{l}\text { 文化的観光 } \\
\text { 交流人口拡大 }\end{array}$ \\
\hline & 宿泊施設 & 善根宿·宿坊 & 善根宿 - 宿坊 & - & 民泊・B\&B \\
\hline & トイレ & 必要最小限 & 必要最小限 & - & $\begin{array}{l}\text { 設置検討 } \\
\end{array}$ \\
\hline & 交通 & $\begin{array}{l}\text { パーク } \\
\text { \&ライド }\end{array}$ & $\begin{array}{l}\text { 交通アクセ } \\
\text { ス整備 }\end{array}$ & - & 駐車場充実 \\
\hline \multirow{3}{*}{ 搴 } & 対象期間 & 3 年 & 3 年 & 7 年 & 5 年 10 年 \\
\hline & 進行管理 & PDCA & PDCA & - & - \\
\hline & 運営体制 & $\begin{array}{l}\text { 熊野古道協 } \\
\text { 働会誐 }\end{array}$ & $\begin{array}{l}\text { 態野克道 } \\
\text { 働会議 }\end{array}$ & - & - \\
\hline
\end{tabular}


B＆B等,民家を活用した宿泊施設の検討」が示され,巡礼路とは 無関係なコンセプトが示される。

ツーリズムの種類としては, 熊野古道 AP2 では「地域の本来的な 魅力を体感できる旅のスタイル」とするカルチュラル・ツーリズ ムへ変化し, 熊野古道 AP3 では熊野古道 AP2 を継承しつつも,「プ ロモーションの重要性」を訴え,地域外といかに繋がるかが示され る。熊野古道 AP4 では地域の「資源を活かして交流人口の拡大,地 域活性化をめざす「文化的観光」をはじめ, 地域資源を生かした体 験型・参加型ツーリズムを提供」するとしている。

来訪者に求めていた社会的責任については熊野古道AP2まで記 述が見られたが, 熊野古道 AP4ではこれまでの「主な成果」欄に

「参詣道ルールの制定と普及・啓発」が記され，「今後の計画」欄 には記されない。一方, 来訪者との関係としては,誘客促進,周遊性・ 滞在性の向上,おもてなしの醸成が項目として列記されている。加 えて, 熊野古道 AP4 では,トイレの整備検討と,駐車場の充実化が それぞれ記されている。

このように, 環境を保全し, 来訪者に相応の社会的責任と負担を 求めるツーリズムから, 交流人口を増加させ, 来訪者の利便性を優 先するツーリズムへと変化していることがうかがえる。また,観光 の対象も,地域全体から特定の資源へと変化している。

4）計画の実施（表一3）

進行管理の記述は熊野古道 AP2 を最後に見られなくなる。また, 個々のアクションを書く事業主体が 1 年ごとに見直すPDCAサ イクルの記述も熊野古道AP3 以降見られなくなる。管理運営計画 の対象期間は, 熊野古道 AP3 以降大幅に延長される。また, 運営体 制として熊野古道AP2までは熊野古道協働会議が示されていたが, 熊野古道 AP3 以降は運営体制に関する記述はなくなる。このよう に, 当初その時点での課題を抽出・解決し, 改訂を繰り返していくこ とで,状況に応じた展開を図ろうとしていた管理運営計画は, 実施 内容の確認方法を持たず,目標を示すのみとなった。

\section{（3）遺産を取り巻く状況の変化}

\section{1）伊勢路と世界遺産}

伊勢路は「紀伊山地の霊場と参詣道」の構成資産として,平成 13 年 (2001) に世界遺産の暫定リストに登録された。平成 14 年 12 月には国史跡に指定され, 文化庁は平成 15 年 1 月,世界遺産登録推 薦書をユネスコに提出した。ICOMOS（国際記念物遺跡会議）は 平成 15 年 10 月の現地調査の結果を受けて,世界遺産委員会に対し 世界遺産リス卜に登録すべきという勧告を行うことを決定,その後, 平成 16 年 6 月に中国蘇州で開催された第 28 回世界遺産委員会に おいて世界遺産に正式登録された。登録に際して付された勧告に 基づき,平成 17 年度には包括的保存管理計画が作成され,ユネスコ 一送付された。その後は 6 年に 1 度の定期報告が義務付けられて おり,平成 22 年度に紀伊山地の霊場と参詣道としては初めての定 期報告を提出している。なお,平成 28 年度に紀伊山地の霊場と参 詣道は追加登録を実施しているが,伊勢路では行われなかった。

2）人口の減少と入込客数の増加

伊勢路の世界遺産登録資産が所在する三重県内の市町は,現在の 大紀町,紀北町,尾熟市,熊野市,御浜町, 紀宝町の 6 市町である 16)。 これら 6 市町の総人口は,平成 13 年に 100,936 人であったのに対 し,平成 28 年には 78,971 人へと減少している。

一方,入込客数は平成 13 年に約 6 万 8000 人だったのが,AP2 発 行前年の平成 16 年には約 15 万にまで増加した。その後平成 20 年までほぼ横ばいで,AP3 発行後の平成 21 年以降再び増加に転じ, 平成 26 年には 428,698 人を記録した。

3）住民組織の状況

住民組織の状況変化については,平成 11 年（1999）に結成され, 伊勢路の資産の掘り起しと峠道の案内の役割を担ってきた「熊野 古道語り部友の会」について把握する。これに関しては記録・公開
されている情報がないため,新聞記事から状況を整理し把握した。

熊野古道 AP1 が発行された平成 13 年から 15 年までは,住民組 織間のネットワークの構築や,語り部会員の組織化,熊野古道保全 への決意表明,世界遺産登録を機に地域の保護意識が高まることへ の期待感を表明する記事があった。平成 16 年には語り部養成講座 があり,ガイドすることへの語り部の満足も表明されている。熊野 古道 AP2 が発行された後の平成 19 年には,救急対応マニュアルの 整備や実際に古道客を救助した記事がみられ,平成 21 年には熊野 古道語り部友の会への功労賞の贈与や,エコツアーが広がっている と評価する記事も見られた。平成 25 年 5 月に皇太子行啓があり, これを回顧する内容が,熊野古道 AP4 が発行される平成 26 年, 27 年にみられ, 熊野古道語り部友の会の活動が着実に充実してきた状 況がうかがえる。一方, 熊野古道 AP3 が発行された平成 20 年には, 若手の語り部会員募集と語り部養成講座の開始を告知する記事が あり,語り部の高齢化と人材不足が課題となってきていることが窥 える。平成 21 年, 23 年, 26 年に,語り部の高齢化と人材不足に関す る記事が登場しており,この課題が解消していないといえる。語り 部の会員数は,記事において 186 人 (平成 14 年),200人 (平成 19 年), 220 人（平成 21 年）と増加していたが,その後, 170 人（平成 26 年) , 160人 (平成 27 年) と減少に転じている。実際に活動し ている人数は, 200 人中 60 人（平成 19 年）,170人中 4 割（平成 26 年) と記事中で紹介されており,実働人数は 60 人〜 70 人程度と 考えられる。

4) 三重県施策の変化 (表一-4)

熊野古道 AP の発行者には, 熊野古道 AP1 において「地域振興部 東紀州活性化プロジェクトグループ」の名称が付されており,三重 県の東紀州地域活性化担当部署と考えられる。組織改編によって, 東紀州地域活性化担当部署は平成 18 年度から政策部,平成 24 年度 には地域連携部一と所属は変化し,平成 29 年度には地域連携部南 部地域活性化局東紀州振興課が相当している。

熊野古道 $\mathrm{AP} 1$ 発行前の平成 13 年度には,県及び市町村で組織す る東紀州地域活性化事業推進協議会により実施されるソフト事業 と,紀北,紀南でそれぞれ検討されている交流拠点整備事業,その他 の事業 1 件で構成されていた。このうち,東紀州地域活性化事業推 進協議会により実施されるソフト事業においては,宿泊施設,体験 交流イベント,食,旅行キャンペーン,情報発信等観光振興に関する 事業と,住民による地域の歴史・文化研究事業である熊野学の取組, 地域活性化の人材を育成する東紀州活性化大学など,観光振興事業 と地域住民の取組支援とがセットで行われていた。一方,交流拠点 整備事業については，「平成 $10 ・ 11$ 年度に実施した民活化可能調 查の結果を受け,平成 12 年度紀南交流拠点については事業主体の 公募を行」い,13 年度「事業主体との契約を」行うとし,紀北交流拠 点については「熊野古道等の新たな機能についても検討し,平成 12 年度中に整備の方向性を決め」,平成 13 年度は「事業構造を明確 にし,事業推進を図」るとしている。こののち,紀北交流拠点は熊野 古道センター一,紀南交流拠点は「紀南中核的交流施設（里創人熊 野俱楽部)」へと展開寸るが,平成 13 年度予算案立案段階ですでに それら整備については一定の方向が打ち出されていたことが確認 できる。

平成 14 年度には,世界遺産総合対策プロジェクト推進事業が新 規に成立する。また,交流拠点整備事業が紀北と紀南に分離し,以降, ア）世界遺産対策に係る事業,イ）紀北交流拠点整備にかかる事業， ウ）紀南交流拠点整備にかかる事業,工）東紀州地域活性化事業推 進協議会等にかかる事業が東紀州活性化担当部署の主たる事業と なる。そこで,以下ではまず,平成 14 年度以降の上記 4 事業につい て事業内容の変遷を検討寸る。

ア）世界遺産対策に係る事業: 平成 $14 \cdot 15$ 年度「世界遺産総合対 策プロジェクト推進事業」平成 16 18 年度「世界遺産 (熊野古道) 
対策推進事業」平成 19 22 年度「世界遺産熊野古道対策推進事 業」平成 $23 \cdot 24$ 年度「古道対策推進事業」と, 平成 23 年度に事業 名から「「吉野・高野・熊野の国」事業」が分離する。

平成 $15 \sim 18$ 年度までは, 熊野古道 $\mathrm{AP}$ の実施を事業の中心に据 え, $15 \cdot 16$ 年度は世界遺産登録記念事業を掲げている。平成 $19 \cdot$ 20 年度は資料がなく詳細不明だが,平成 21 年度にはアクションプ ログラムの文言は消减し，「登録 5 周年記念」の事業の実施を図っ ている。平成 22 年度には和歌山県・奈良県との広域観光ルート開 発,観光プログラム開発,冊子作成へ变化する。平成 23 年度には, 広 域観光の推進が「吉野・高野・熊野の国」事業として分離,冊子作 成とウオークイベントの実施が「古道対策推進事業」として残り, 平成 24 年度で廃止となった。

イ）紀北交流拠点整備: 平成 14 年度において「熊野古道センター (仮称) の事業化に向けた取り組み」を実施している。平成 15 年 度〜 18 年度にかけて建設工事を行い, 平成 18 年度末に開館。その 後は運営費が毎年計上される。運営目的は平成 19〜23 年度は「交 流促進」が挙げられていたが,平成 $24 \cdot 25$ 年度は「集客」へと変化 し,平成 26 年度からは「集客交流」となっている。

ウ）紀南交流拠点整備: 平成 14 年度には基本計画が策定され, 平 成 $15 \sim 18$ 年度は紀南集客に関するソフト事業が行われている。平 成 16 年度以降,三重県の予算書には中核的交流施設整備が平成 28 年度まで継続する。事業は,平成 17 年度に策定された『紀南中核 的交流施設整備基本構想』17)によれば,民間事業者が整備を実施し, これに三重県と関係市町が整備費等を 10 年間で上限 30 億円補助 するとされる。平成 18 年度に補助事業者が決定し, 平成 21 年度に 「里創人熊野俱楽部」として開業した。

紀北・紀南交流拠点整備は, 後述する「三重県中南部地域広域活 性化計画」において,拠点施設として位置づけられている。

工）東紀州地域活性化事業推進協議会 : 観光振興事業と地域住民 の取組支援とがセットで行われていた事業は平成 16 年度まで継 続する。しかし, 人材育成事業は平成 16 年度で終了, 調査研究事業 である熊野学に関する事業も平成 18 年度を最後に予算書から文 言が消滅する。替わって平成 19２5 年度には「東紀州観光まちづ くり公社」が登場し,「観光振興,産業振興およびまちづくりを総合 的に推進」するとなる。さらに平成 26 年度からは「東紀州地域振 興公社」へと変化し，「観光商品づくりやエージェントセールス」 などによる「集客交流」と「物産展等を通じた販路開拓」を行うと 変化している。

オ) その他の事業: 上述の 4 事業のほかの事業について概観する。

平成 15 17 年度においては,世界遺産登録プレ事業が実施（平 成 15 年度) されているほか,エコツーリズム推進事業モデル地区 に選定され（平成 16１8 年度）, 体験型観光とその人材育成を実 施する「紀北で体験しよらい事業」と「体験の達人育成支援事業」

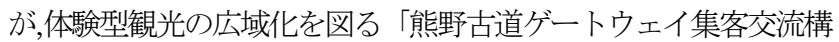
築事業」が実施されている。一方,PR 事業として「紀北紀南連携・
熊野古道パワーアップ事業」が,観光客の意向調査である「熊野古 道C S 調查事業」が実施され,尾鷲ヒノキの商品開発に関する「「尾 熟ヒノキ」で熊野古道関連製品をつくろう! 事業」も実施される。 このほかダイビング関係事業が 2 件実施されている。

平成 18２0 年度においては，「伊勢と熊野の二つの文化圏を結 ぶ「熊野古道伊勢路」を多くの人々が通して歩ける環境やしくみ づくり」を行う「熊野古道伊勢路を結ぶしくみづくり事業」が開始 (平成 19 年度) し,以降平成 21 年度開始の「熊野古道伊勢路踏破 支援緊急雇用創出事業」とともに平成 24 年度まで継続する。

平成 21２3 年度においては,広域的な交流による地域活性化を 支援する地域自立・活性化総合支援制度に基づく社会資本整備総 合交付金が交付され,この要件に基づいた「三重県中南部地域広域 活性化計画（計画期間 : 平成 19〜23 年度)」に基づいた世界遺産 登録 5 周年記念事業（平成 21 年）や,首都圈での熊野古道に関す る情報発信事業が実施される。また,平成 21〜23 年度には, 「熊野 古道等観光ツアーガイド養成ふるさと雇用再生事業」として，「熊 野古道の語り部をはじめとする東紀州地域の観光ツアーガイドの 養成」を行う事業が行われ,平成 21 年度には熊野古道センターに おいて熊野古道等の「地域資源の調査研究」を実施する事業が開 始し,平成 25 年度まで継続。一方,高速道路延伸を契機とした熊野 古道との関係を明示しない広域観光プランの開発を行う「南三重 地域広域観光推進緊急雇用創出事業」が平成 21 年度から 25 年度 にまで継続して実施されるほか，「観光産業プロデュース」を東紀 州観光まちづくり公社が実施する「東紀州観光まちづくりパワー アップ事業」が平成 $22 \cdot 23$ 年度に実施されている。また,商品開 発,販売促進をめざす「東紀州地域ブランド商品開発・販売促進子 るさと雇用再生事業」と「東紀州地域力再生支援事業」が平成 21 ～ 23 年度にかけて実施される。このほか,平成 $22 \cdot 23$ 年度には「イ ンターンシップチャレンジプロデューサー養成ふるさと雇用事業」 として長期インターンシップにかかる事業が,平成 23 年度には「紀 州地域資源活用支援事業」として「学生等の派遣」による新たな事 業展開をめざす事業が実施されている。

平成 24〜26 年度にかけては,商品開発・販売促進をめざす「東 紀州産品販路拡大支援事業」が実施される。また,平成 26 年度の 世界遺産登録 10 周年に向けた観光キャンペーン事業として,平成 $24 \cdot 25$ 年度「東紀州観光プロジェクト事業」,平成 25 年度「東紀 州地域誘客促進緊急雇用創出事業」，「熊野古道情報提供強化緊急 雇用創出事業」,平成 $25 \cdot 26$ 年度「熊野古道世界遺産登録 10 周年 事業」が実施される。このほか,平成 25 年度には,「世界遺産を活 用した鬼力ある観光商品の企画造成」を行う「紀南地域観光商品 企画造成緊急雇用創出事業」が実施される。

平成 $27 \cdot 28$ 年度には,その他事業は実施されていない。

5)まとめ

平成 15 年度の ICOMOS 現地調査は,遺産の価值や保全状況を 調査して世界遺産登録の審査をするもので，「保全」が注目された

表一4 三重県施策の変化

\begin{tabular}{|c|c|c|c|c|c|c|}
\hline 期間 & 平成 14 年度以前 & 平成 $15 \sim 17$ 年度 & 平成 $18 \sim 20$ 年度 & 平成 $21 \sim 23$ 年度 & 平成 $24 \sim 26$ 年度 & 平成 27 年度以降 \\
\hline 熊野古道AP との関係 & 熊野古道AP1 以前 & 熊野古道 AP1 AP2 & 熊野古道 AP2～AP3 & \multicolumn{2}{|c|}{ 熊野古道 AP3 AP4 } & 熊野古道AP4 以降 \\
\hline ア）世界遺産 & 熊野古道AP策定 & $\begin{array}{l}\text { 熊野古道AP の実 } \\
\text { 施・登録記念事業 }\end{array}$ & 熊野古道AP の実施 & $\begin{array}{l}\text { 登録 } 5 \text { 周年 } \\
\text { 広域観光 }\end{array}$ & 広域観光 & 広域観光 \\
\hline イ）熊野古道センター & 事業化取組 & 建設工事 & 開館・運営 & 交流促進 & 集客 & 集客交流 \\
\hline $\begin{array}{l}\text { ウ）紀南中核的交流 } \\
\text { 施設 } \\
\end{array}$ & 基本計画 & 施設整備 & 施設整備補助金 & $\begin{array}{l}\text { 開業 } \\
\text { 施設整備補助金 }\end{array}$ & 施設整備補助金 & 施設整備補助金 \\
\hline $\begin{array}{l}\text { 工）東紀州活性化 } \\
\text { 事業推進協議会 } \\
\end{array}$ & $\begin{array}{l}\text { 観光振興 } \\
\text { 地域住民取組支援 }\end{array}$ & $\begin{array}{l}\text { 観光振興 } \\
\text { 地域住民取組支援 }\end{array}$ & $\begin{array}{l}\text { 観光振興・産業振 } \\
\text { 興・まちづくり } \\
\end{array}$ & $\begin{array}{l}\text { 観光振興・産業振興・ } \\
\text { まちづくり }\end{array}$ & $\begin{array}{l}\text { 集客交流 } \\
\text { 販路拡大 }\end{array}$ & $\begin{array}{l}\text { 集客交流 } \\
\text { 販路拡大 }\end{array}$ \\
\hline オ）その他事業 & $\begin{array}{l}\text { 観光コンテンツ整 } \\
\text { 備 }\end{array}$ & $\begin{array}{l}\text { 世界遺産登録プレ } \\
\text { 事業 } \\
\text { 体験型観光と人材 } \\
\text { 育成 }\end{array}$ & $\begin{array}{l}\text { 伊勢路を結ぶしく } \\
\text { みづくり }\end{array}$ & $\begin{array}{l}\text { 伊勢路を結ぶしくみづ } \\
\text { くり・人材育成・地域 } \\
\text { 資源研究・登録 } 5 \text { 周 } \\
\text { 年・観光振興・商品開 } \\
\text { 発・販売促進・インタ } \\
\text { ーンシップ・学生 }\end{array}$ & $\begin{array}{l}\text { 登録 } 10 \text { 周年事業観 } \\
\text { 光キャンペーン商品 } \\
\text { 開発・販売促進 }\end{array}$ & \\
\hline
\end{tabular}


と考えられる。一方,世界遺産登録後は,地域住民が関わる世界遺産 条約上の必要な取組はなく,世界遺産登録資産として「保全」する ことについては,関心が薄れていくものと考えられる。

来訪者は平成 16 年と平成 21 年を契機に 2 度大きく増加してい る。一方で,地域の人口減少は着実に進んでいる。住民組織の活動 は, 熊野古道語り部友の会の場合, 平成 19 年頃から若手参加者の不 足が表明されており,それは以降継続する。新規参加者の確保は実 現していないことが看取できる。

三重県の施策は,平成 13 年度頃,地域住民の人材育成や活動の支 援に中心があった一方で,この頃既に後の熊野古道センターや紀南 中核的交流施設といった大型施設の建設・誘致を行う方向が打ち 出されていた。また, 熊野古道 AP1 策定後は, 登録記念事業, 体験型 観光にかかる事業,それにかかる人材の育成,伊勢路を結ぶ仕組み づくりにかかる事業,など熊野古道 AP の実施とその方向性にそっ た施策が展開し,登録 5 周年をはさんで次第に縮小しながらも平成 24 年度頃までは継続する。しかし平成 26 年度の登録 10 周年を控 えた時期に, 観光振興と商品開発・販路拡大に施策は変化し,熊野古 道 AP との関係性はほとんど見られなくなる。

\section{4. まとめ}

熊野古道AP1が策定されたのは,世界遺産登録前のICOMOS調 查員が調査を行う前であり, 伊勢路の保護を中心とした気運が高ま っていた時期と考えられる。そのため策定に幅広い人々が参画し て, 遺産の保護と, 遺産の価值である巡礼に即したツーリズムを両 立させようとした。三重県はAP1に即した事業を展開するととも に,環境省のエコツーリズムモデル事業を実施し, 住民組織は活動 内容を充実させていった。この時期, 熊野古道 AP は遺産の管理運 営計画として有効に機能していたと考えられる。しかし,AP1,AP2 によっては大幅な入込客数の増加はもたらされなかった。世界遺 産登録による大幅な来訪者数の増加を期待していた三重県は,熊野 古道AP1に記載されていなかった大規模宿泊施設や国土交通省の 広域的活性化交付金事業による登録 5 周年事業などを活用し, 広域 観光による集客を図った。AP3 は策定参加者が限定的で,域外の意 見を聞くことになったため,内容は三重県の方針に近いものへ変化 した。一方,人手不足を表明していた住民組織に対しては,支援と顕 彰による人手確保を示すにとどまり,行政と住民の連携は示されな くなった。この後, 入込客数は急増し, 登録 10 周年を過ぎた時 期,AP4 では住民も民泊やB\&Bなど遺産の価值とは無関係なツー リズムへの参加を促されることになった。一方三重県は AP4 に即 した事業は実施しなくなった。

このように『熊野古道 $\mathrm{AP} 』 の$ 策定参加者は幅広い人々から限定 的な関係者に変化した。このことは,多数の地域住民から「熊野古 道関係者」を切り離し,結果,住民組織の参加者減少を招いたと考え られる。また,行政は住民を保護ではなくツーリズムに参加させよ うと変化した。これは,エコツーリズム推進モデル事業の期間が終 了し,広域的な地域交流による活性化を目的として, 行政主体で行 われた 5 周年記念事業を機に域外への意識が強くなり,来訪者数の 増加に意識が移ったためと考えられる。

さらに,熊野古道 AP は次第に行政の管理運営計画としては機能 しなくなっていった。これは世界遺産登録という明確な目標が,登 録によって曖昧になったことと, 前述の国による広域的な交流支援 事業に基づく地域活性化計画が策定され, 熊野古道 $\mathrm{AP}$ 以前から計 画された施設の建設・維持管理に予算が配分され,管理運営に必要 な地域住民による古道の保全や体験型観光の活動支援が手薄にな ったためと考えられる。

このように遺産の管理運営計画の策定に地域住民が関わらなく なると、計画に基づく取組に住民は参加しなくなると考えられる。 また、このことは、管理運営計画の実効性を弱め、管理運営の趣旨
や実施内容の変質を招くと考えられる。世界遺産においては登録 による大幅な来訪者数の増加が期待されるとともに、地域活性化 や観光においては広域連携がうたわれ外との繋がりが意識されが ちであるが、実効性のある遺産の管理運営計画を策定し、実施す るためには、まず策定作業に地域住民が参加し、改訂作業にも地 域住民が参加し続ける仕掛けが必要であると考えられる。そのた めには、管理運営に参加し続ける人々への連携と支援の施策が必 要であると考えられる。

謝辞: 本研究は JSPS 科研費 $16 \mathrm{~K} 08125$ の助成を受けたものです。

\section{補注及び引用文献}

1）例えば,国土交通省では 2008 年頃から地域振興の文脈において，「多様な主体による 協㗢」を進めるとしている。国土交通省ホームページ<http://www.mlit.go.jp/ kokudoseisaku/chisei/kokudoseisaku_chisei_tk_000061.html>, 2017.8.24参照

2) World Heritage Committee Decision 31COM13B: The "fifth C" for "Communities" : World Heritage Center ホームページくhttp://whc.unesco.org/en/decisions/5197>, 2017.8.24 参照

3) UNESCO,ICCROM,ICOMOS,IUCN (2013) :MANAGING CULTURALWORLD HERITAGE, pp14

4) 稲葉信子 (2011) : 変化をマネジメントする一対処療法からの脱却,そして遺産ガバナ ンスヘー : 地域における遺跡の総合マネジメントー平成 22 年度遺跡整備・活用研究 集会 (第5 回) 報告書一: 独立行政法人国立文化財機構奈良文化財研究所,pp42

5）石見銀山協働会議（2006）: 石見銀山行動計画:石見銀山を未来に引き継ぐために

6) 富士宮市教育委員会 (2013)：富士山世界文化遺産富士宮市行動計画

7）伊勢路は、世界遺産登録推薦文においては「伊勢神宮」と熊野三山を結ぶ参詣道とさ れていたが、近年、伊勢から熊野まで礼拝施設や見所等装置性を伴う巡礼路であった ことが指摘されており、総合的な管理が必要である。伊藤文彦,伊藤々,武正憲 (2017) : 熊野参詣道伊勢路における巡礼空間の装置性: ランドスケープ研究 80(5),pp589-592 8) 平野昌 (2011) : 熊野古道アクションプログラムから考える遺産のマネジメント : 地 域における遺跡の総合的マネジメントー平成 22 年度遺跡整備・活用研究集会 (第 5 回）報告書一: 独立行政法人国立文化財機構奈良文化財研究所, pp 46-pp49

9）西川亮 (2014) : 三重県における熊野古道の保全と活用に関寸る研究 : 観光文化 $=$ Tourism culture 38(2) :日本交通公社, pp38-pp41

10）伊勢路に関しては別に『世界遺産「紀伊山地の霊場と参詣道」保存管理計画』があ る。これは文化財保護法に基づき史跡に指定され世界遺産に登録された範井について, 史跡の現状変更や整備の方針について定めたもので,行政と専門家によって策定され たもので,本稿で扱う管理運営計画とは性格が異なる。

11）本中眞 (2005)：「紀伊山地の霊場と参詣道」の世界遺産登録の意義と課題 : 世界遺 産 紀伊山地の霊場と参詣道

12) 三重県 (2017) :22 推計人口 (総数) :三重県ホームページ

$<$ http://www.pref.mie.lg.jp/DATABOX/26025004161.htm>, 2017.12.1 参照

13）入込客数は東紀州地域振興公社公表数值による。東紀州地域振興公社 <http://www. kumanokodo-iseji.jp/higashikishu/number_visitors.html>, 2017.9.1 参照

14）朝日新聞及ひ読売新聞のデータベースで,平成 13 年度から平成 28 年度まで「熊野 古道語り部友の会」で検索し抽出されたそれぞれ 25 件 38 件の記事を対象とする。

15) 三重県のホームページに掲載されている担当部局別予算一覧表 (部局名称,事業名称, 細事業名称,事業費,県費,事業概要（目的）,政策体系名称等の項目を表示）から，「事業 名称」に「東紀州」「世界遺産」「熊野古道」を含む事業を抽出した。また,平成 19 年 度と平成 20 年度の予算一覧表は公表されていないことから,三重県議会の会議録から 「予算に関する説明書」を閲覧した。その結果,156 件の事業が抽出された。三重県 (2009)：予算に関する説明書:三重県議会定例会臨時会会議録平成 19 年 (別冊) 上, 三重県 (2010)：予算に関寸る説明書:三重県議会定例会臨時会会議録平成 20 年 (別 冊) 四分冊の一,三重県議会図書室蔵

16) 平成 17 年 2 月から平成 18 年 1 月にかけてこれらの地域では市町村合併が行われ ており,合併以前の人口は以下の市町村の人口を合計している。尾鷲市,熊野市,紀和町， 大宮町,紀勢町,大内山村,紀伊長島町,海山町,御浜町,紀宝町,鵜殿村。

17）三重県 (2005)：紀南中核的交流施設整備基本構想 